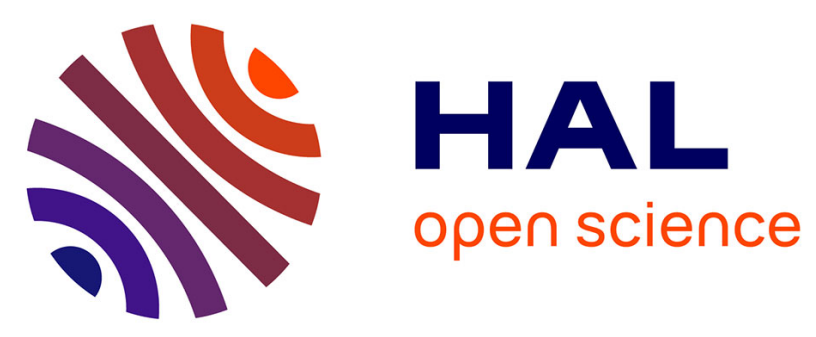

\title{
Performances of auto and allotriploids in salmonids. I. Survival and growth in fresh water farming
}

Edwige Quillet, B. Chevassus, J.M. Blanc, Francine Krieg, Daniel Chourrout

\section{To cite this version:}

Edwige Quillet, B. Chevassus, J.M. Blanc, Francine Krieg, Daniel Chourrout. Performances of auto and allotriploids in salmonids. I. Survival and growth in fresh water farming. Aquatic Living Resources, 1988, 1, pp.29-43. hal-02718118

\section{HAL Id: hal-02718118 \\ https://hal.inrae.fr/hal-02718118}

Submitted on 1 Jun 2020

HAL is a multi-disciplinary open access archive for the deposit and dissemination of scientific research documents, whether they are published or not. The documents may come from teaching and research institutions in France or abroad, or from public or private research centers.
L'archive ouverte pluridisciplinaire HAL, est destinée au dépôt et à la diffusion de documents scientifiques de niveau recherche, publiés ou non, émanant des établissements d'enseignement et de recherche français ou étrangers, des laboratoires publics ou privés. 


\title{
Performances of auto and allotriploids in salmonids I. Survival and growth in fresh water farming
}

\author{
Edwige Quillet, Bernard Chevassus, Jean-Marie Blanc ${ }^{(1)}$, Francine Krieg \\ and Daniel Chourrout
}

Laboratoire de Génétique des Poissons, LNRA, $7835^{\circ}$ Jouy-en-Josas (France)

(1) Station d'Ilydrobiologie, INRA, Saint-Pé-sur-Jicielle, 6 4310 Ascain (France).

Accepted October 9, 1987 .

Quillet E., B. Chevassus, J. M. Blanc, F. Krieg, D. Chourrout, Aquat. Liring Resour., 1988, 1, 29-43.

Abstract

Survival and growth performances of autotriploids in rainbow trout (Salmo gairdneri) and three types of triploid hybrids between female rainbow trout and brown trout males (Salmo trutta), coho salmon males (Oncorhynchus kisutch) and brook trout males (Salcelinus fontinalis) were analysed relatively to the parental species in freshwater farming conditions. At the end of the immature period, autotriploids exhibit moderate but significant depression relative to the control for both survival (about 25\% depression) and growth (10 to 15\% depression). Most of this depression is established during the first three months of life, triploids appearing very similar to the control later on. At the onset of sexual maturation at 2 years old, relative value of triploids becomes higher than that of the control, for both survival and growth. Long term evaluation $\left(2^{+}\right.$or $\left.3^{+}\right)$balances in favor of triploids with particular advantage for triploid females. Triploid hybrids exhibit much more important depression in early survival (up to $60 \%$ ). Later on, their survival remains always lower than those of parental controls. Their growth performances are intermediate between their two parental species. Despite a relative advantage for these groups during the onset of sexual maturation in control groups, especially for growth, long term evaluation is in favor of diploid rainbow trout, but in some specific cases.

Keynords : Salmonids, triploidy, hybridization, survival, growth.

Performances chez des salmonidés auto et allotriploïdes. I. Surtie et croissance en élerage intensif en cau douce.

Résumé

Nous avons comparé les performances de survie et de croissance de truite arc-en-ciel triploides (Salmo gairdneri) et de trois hybrides triploïdes entre des femelles de cette espèce et des mâles de truite commune (Salmo trutta), de saumon coho (Oncorhynchus kisutch) et d'omble de fontaine (Salcelinus fontinalis) à celles des différents témoins parentaux dans le cadre d'un élevage intensif en eau douce. Les truites arc-en-ciel triploïles présentent à la fin de la période immature $\left(1^{*}\right)$ une dépression modéré, mais significative de leurs performances de survie (environ $25 \%$ ) et de croissance $(-10$ à $-15 \%)$. L'essentiel de cette dépression s'établit au cours des 3 premiers mois, l'écart entre diploỉdes et triploïdes étant plus réduit par la suite. Lors de la maturation sexuelle, les triploïdes deviennent supérieurs au témoin, en survie comme en croissance. Le bilan à long terme $\left(2^{+}\right.$ou $\left.3^{+}\right)$ s'établit en faveur des triploides, un avantage particulièrement net apparaissant dans le cas des femelles triploïdes. Les hybrides triploïdes présentent une dépression de survie précoce beaucoup plus marquée. Ultérieurement, leur survie reste toujours inférieure à celle des témoins parentaux. Leurs performances de croissance sont comprises entre celles des espéces parentales. Malgré un avantage relatif de ces groupes lors de la maturation sexuelle (en croissance notamment), le bilan à long terme reste en faveur de la truite arc-en-ciel diploïde, sauf dans certains cas particuliers.

Mots-clés : salmonidés, triploïdie, hybridation, survie, croissance. 


\section{INTRODUCTION}

The chromosome set manipulation techniques have been extensively investigated in fish in recent years. Theoretic and practical interest of resulting individuals (gynogenetics, androgenetics, induced polyploids) was extensively discussed (see revicws of Purdom, 1983; Thorgaard, 1983, 1986; Chevassus, 1987; Chourrout, 1987). Triploidy is valuable for production of sterile individuals. It also proved to be an efficient way of increasing survival of interspecific hybrids, (Chevassus et al., 1983; Scheerer and Thorgaard, 1983; Arai, 1984) which may be helpfull to produce hybrids with desirable qualities of both parental species. Particular interest lics in hybrids with specific resistance to disease (Dorson and Chevassus, 1985a, $b$; Parsons et al., 1986). Up to now, much of the work has been done on optimization of induction techniques (see review of Chourrout, 1987). In salmonids, heat shocks proved to be a very efficient technique in inducing high frequency of triploids, and a much more appropriate technique than others (i. e., pressure shocks, that are also efficient; see review of Chourrout, 1987) to be used for large scale production. As a matter of fact, this technique is already diffused in private farms. Nevertheless, there is still few information on performances of these animals.

If much has been done on surveying sexual maturation of triploids (Benfey and Sutterlin, 1984; Benfey, 1985 in Atlantic salmon; Johnson et al., 1986, in coho salmon; Lincoln, 1981 $a, b$; Lincoln and Scott, 1983, 1984; Solar et al., 1984; Jalabert, pers. comm. 1985, in rainbow trout), data on survival and growth are less accurate, as they have sometimes been established with very few animals (Utter et al., 1983; Benfey and Sutterlin, 1984; Johnson et al., 1986; Thorgaard, 1986). Purpose of the present study was to provide extensive information on survival and growth performances of triploid rainbow trout and its triploid hybrids with other salmonids over a complete brecding cycle in freshwater farming.

\section{MATERIAL AND METHODS}

\section{Brood stock}

Four salmonid species were collected. In all cases, but for experiment $82 \mathrm{C}$ (table 2), rainbow trout (Salmo gairdneri R.) and brown trout (Salmo trutta L.) breeders were kept in INRA experimental fish farm at Gournay-sur-Aronde (Oise) (INRA strains in both cases). In experiment $82 \mathrm{C}$, rainbow trout and brown trout breeders were obtained from the stocks of INRA experimental fish farm at Lees$\Lambda$ thas (Pyrénées $\Lambda$ tlantiques). Coho salmon (Oncorhynchus kisutch) were introduced from private freshwater (80A, 82A) and seawater (81A) French farms. Only brook trout males (Salcelinus fontinalis) were available and came from domestic population in north of France (Etrun; Pas-de-Calais).

\section{Fertilization procedure}

Nine successive experiments were performed, from November 1980 to January 1983 (tables 1, 2). In each

Table 1. - Crossing design and nomenclature of the different groups.

\begin{tabular}{|c|c|c|c|c|c|}
\hline Female & Male & $\begin{array}{c}\text { Rainbow } \\
\text { trout } \\
\text { (R) }\end{array}$ & $\begin{array}{l}\text { Brown } \\
\text { trout } \\
\text { (B) }\end{array}$ & $\begin{array}{l}\text { Coho } \\
\text { salmon } \\
\text { (C) }\end{array}$ & $\begin{array}{c}\text { Brook } \\
\text { trout } \\
\text { (O) }\end{array}$ \\
\hline $\begin{array}{l}\text { Rainbow trout } \\
\text { (R) }\end{array}$ & $\begin{array}{l}\text { NF } \\
\text { HS }\end{array}$ & $\begin{array}{l}\text { R2 } \\
\text { R3 }\end{array}$ & $\begin{array}{l}\mathrm{RB}^{+} \\
\mathrm{R} 2 \mathrm{~B}\end{array}$ & $\begin{array}{l}\mathrm{RC}^{+} \\
\mathrm{R} 2 \mathrm{C}\end{array}$ & $\begin{array}{l}\mathrm{RO}^{+} \\
\mathrm{R} 2 \mathrm{O}\end{array}$ \\
\hline $\begin{array}{l}\text { Brown trout } \\
\text { (B) }\end{array}$ & NF & 1 & B2 & 1 & I \\
\hline $\begin{array}{l}\text { Coho salmon } \\
\text { (C) }\end{array}$ & NF & I & 1 & $\mathrm{C} 2$ & 1 \\
\hline
\end{tabular}

NF : normal fertilization.

HS : heat shock $\left(26^{\circ} \mathrm{C}, 20 \mathrm{~min}\right)$.

+ : diploid hybrids, with poor or no survival at early stages.

case, eggs of several females per species were stripped by abdominal pressure, and artificial fertilization performed using saline buffered diluent (Billard, 1977). Eggs from rainbow trout females were fertilized by a sperm mixture from 3 to 10 males of all the available species, while brown trout and coho salmon eggs were fertilized only by homologous semen, as presented in table 1.

Eggs from the different females were usually pooled, except in experiment 80B, in which eggs of the individual females were fertilized and kept separately until the end of hatching. Triploidization treatment was the one described by Chourrout (1980) and Chourrout and Quillet (1982) (heat shock at $26^{\circ} \mathrm{C}$ lasting $20 \mathrm{~min}$ ), which proved to be highly efficient on rainbow trout eggs; the same treatment also proved to induce very high rates of triploid hybrids involving that species as maternal species (Chevassus et al., 1983).

\section{Control of the nature of individuals}

Early karyological and biochemical controls were performed in exp. 80A and 80B. Results are presented in the paper by Chevassus et al. (1983). Later on, we have admitted that the nature of the individuals resulting from the treatments was the expected one. Now, Chourrout (1986) has recently demonstrated across karyological examinations that when heat shocks are applied, diploids are directly replaced by triploids, with very limited occurrence of ancuploidy, conversely to what is observed with suboptimal pressure shocks. Therefore, in the case of homospecific 
crosses, heat shocks would result in only diploids (fertile) and triploids (supposed to be sterile). Following maturation up and examination of gonads after maturation provided a control a posteriori of the frequency of triploids in experimental populations. This was done in autotriploids in several experiments: whatever experiment, we usually found very few fertile animals (usually 3 to $5 \%$, up to $13 \%$ in exp. $82 \mathrm{~A}$ ), thus indicating high efficiency of the triploidization treatments.

\section{Rearing facilities}

Rearing facilities were the following, depending on the experiments (sce table 2):

- a recirculated system (Jo) stabilized at $10 \pm 0,5^{\circ} \mathrm{C}$ used for incubation and carly fry development, and located at INRA station of Jouy-enJosas (Yvelines). When long term rearing was planned, eggs were transported into experimental farms at eyed stage.

- the INRA cxperimental fish farm of Gournaysur-A ronde (Gr) supplied with spring water (temperature ranging from 6 to $16^{\circ} \mathrm{C}$ ).

- the INRA hatchery of Saint-Pée-sur-Nivelle (Sp), supplied with filtered water from river Nivelle (temperature ranging from $8^{\circ} \mathrm{C}$ to $13^{\circ} \mathrm{C}$ ).

In all cases, eggs of the different groups were hatched in separated trays until the end of startfeeding, and then reared separately up to 7 to 12 months (20 to $50 \mathrm{~g})$ in fiber tanks and kept under standardized conditions.

Later on, the different groups were tagged by finclipping (at least 100 individuals per group) and mixed in larg concrete ponds for long term growth study. During the first year, all fish were fed ad libitum twice a day on commercially produced dry pelleted food. Later on, standard rationing tables were applied.

\section{Study of performances}

Three main periods were defined during the life of the fish to study performances: (1) hatchery period $P_{1}$, from fertilization to about 50 days after start of feeding; (2) immature period $P_{2}$, which extends until the fish are about 20 months $\left(1^{+}\right)$; (3) maturation period $P_{3}$, which includes both the first maturation cycle at 2 years and the following maturation cycle when it is analysed. Exact durations of $P_{1}, P_{2}, P_{3}$ for the different experiments are reported in table 2 .

\section{Surrital}

Survival was recorded at the end of each period. Daily mortality rate $(m)$ for the different periods was defince as:

$$
\mathrm{N}_{f}=\mathrm{N}_{i}(1-m)^{d}
$$

where $N_{i}$ and $N_{f}$ are the initial and final numbers of fish (or ova in the case of $P_{1}$ ), and $d$ the duration in days of the period; $m$ is given in per thousands per day.

\section{Growth rate}

Early growth rate was cvaluated by mass weighing of 50 to 100 fish per group.

Later on, weight was individually recorded on 50 fish per group. Daily specific growth rate $\alpha$ (in percent of body weight) is calculated (rom:

$$
\mathrm{W} f=\mathrm{W} i(1+\alpha)^{d}
$$

with $W i=$ mean weight at the beginning of the period, W $f=$ mean weight at the end of the period and $d=\mathrm{du}$ ration in days of the period.

At two years old, maturing fish were recorded on a phenotypic basis, and tagged with Alcyan blue spots on fins, hence their further growth could be analysed separctely.

Consequences of triploidy on sexual maturation of both auto and allotriploids will be dealt with specific analysis in another paper (Chevassus et al., unpublished data), but some informations about occurence of maturation in the populations analysed here are necessary with regards to growth analysis: in the rainbow trout strains analysed and in our rearing conditions, $97 \%$ of males and about $75 \%$ of females lirst mature at 2 years, whereas in brown trout populations, more than $80 \%$ of males but only few females

\begin{tabular}{|c|c|c|c|c|c|c|c|}
\hline \multirow[b]{2}{*}{ Experiment } & \multirow{2}{*}{$\begin{array}{l}\text { Number of } \\
\text { Rainbow trout } \\
\text { females }\end{array}$} & \multirow[b]{2}{*}{ Experimental groups } & \multirow{2}{*}{$\begin{array}{c}\text { Mace of } \\
\text { incubation } \\
\left({ }^{\circ}\right)\end{array}$} & \multirow{2}{*}{$\begin{array}{l}\text { Hatching } \\
\text { and raising } \\
\left({ }^{\circ}\right)\end{array}$} & \multicolumn{3}{|c|}{ Age at the different period $\left({ }^{b}\right)$} \\
\hline & & & & & $\mathbf{P 1}$ & $\mathbf{P} 2$ & P3 \\
\hline $80 \mathrm{~A}$ & 12 & R2, R3, R2B, R2C, R2O & Jo & Gr & $0-105$ & $105-656$ & $656-1412$ \\
\hline $81 \mathrm{~A}$ & 6 & R2, R3, R2B, R 2C, B2, C2 & Jo & Gr & $0-90$ & $90-593$ & $593-1194$ \\
\hline $82 \AA$ & 28 & $\mathrm{R} 2, \mathrm{R} 3, \mathrm{R} 2 \mathrm{~B}, \mathrm{R} 2 \mathrm{C}, \mathrm{B} 2$ & Jo & Gr & $0-110$ & $110-593$ & $593-1043$ \\
\hline $82 B$ & 41 & R2, R3 & $\mathrm{Gr}$ & Gr & $0-90$ & $90-575$ & $575-1024$ \\
\hline $83 B$ & 2 & R2, R3 & Jo & Go & $0-81$ & l & l \\
\hline $83 \mathrm{C}$ & 34 & R2, R3 & Jo & Sp & 0. 96 & 1 & i \\
\hline
\end{tabular}

Table 2. - Experimental groups and characteristics of the different experiments.

$\left({ }^{\circ}\right)$ see in text for description of experimental structures. $\left({ }^{6}\right)$ age in days post fertilization. 
mature at that age. All fish are mature at 3 years old. In autotriploids, only males are affected by sexual maturation (gonadal growth is observed, but they keep lower gonado-somatic index than diploids), and females remain fully sterile as this was described in several studies previously cited. The same phenomenon is encountered in the case of allotriploids (Chevassus et al., 1985; Quillet, 1986).

\section{Within group variability}

At each date of measurement, individual data allowed for each group calculation of the coefficient of variation $\mathrm{CV}$, as standard deviation expressed as a percentage of the mean.

In the particular case of experiment $82 A$, when fish were about 9 months old, number of data was extensively increased ( 250 fish per group) in order to get more precise estimation of within group variability and to describe the distributions of the different populations.

\section{Statistical methods}

Normality of wcights was tested by computation of Spearman's coefficients for skewness $\left(g_{1}\right)$ and kurtosis $\left(g_{2}\right)$ (as defined in Sokal and Rohlf, 1981). Asymetry to the right was usually detected in young fish, but this asymetry tended to decrease as time gocs, and was not important enough for a log-transformation (Chevassus, 1976) to be required. So, normality was
Table 3. - Early survival rate (in percents of inseminated ova) in the different experiments.

\begin{tabular}{cccc}
\hline $\begin{array}{c}\text { Control } \\
\text { Experiment( }\end{array}$ & R2 & B2 & C2 \\
\hline $80 \mathrm{~A}$ & 54.6 & $\mathrm{nr}^{(b)}$ & $/$ \\
$80 \mathrm{~B}$ & 58.3 & $/$ & $/$ \\
$81 \mathrm{~A}$ & 77.1 & 83.5 & 14.6 \\
$82 \mathrm{~A}$ & 89.7 & 67.7 & 26.3 \\
$82 \mathrm{~B}$ & 79.6 & $/$ & $/$ \\
$82 \mathrm{C}$ & 71.3 & $/$ & $/$ \\
$82 \mathrm{D}$ & 70.9 & $/$ & $/$ \\
$83 \mathrm{D}$ & 88.2 & $/$ & $/$ \\
$83 \mathrm{C}$ & 48.4 & $/$ & $/$ \\
\hline Mean & 70.9 & 75.6 & 20.5
\end{tabular}

( $\left.{ }^{\circ}\right)$ Age at measurement for the different experiments is given in table 2.

(b) Not recorded.

accepted, and analysis performed on non transformed data.

Analysis of variance was performed with classical models (one or two way ANOVA, with or without replicates. Sokal and Rohlf, 1981).

Some multiple comparisons were also performed with test of Student-Newman-Keuls (Scherrer, 1984).

Analysis of percentages $p$ (i. c. survival rates) were performed on transformed data $p^{\prime}=\arcsin \sqrt{p}$.

Finally, assuming that coefficient of variation remains constant over short range of growth within

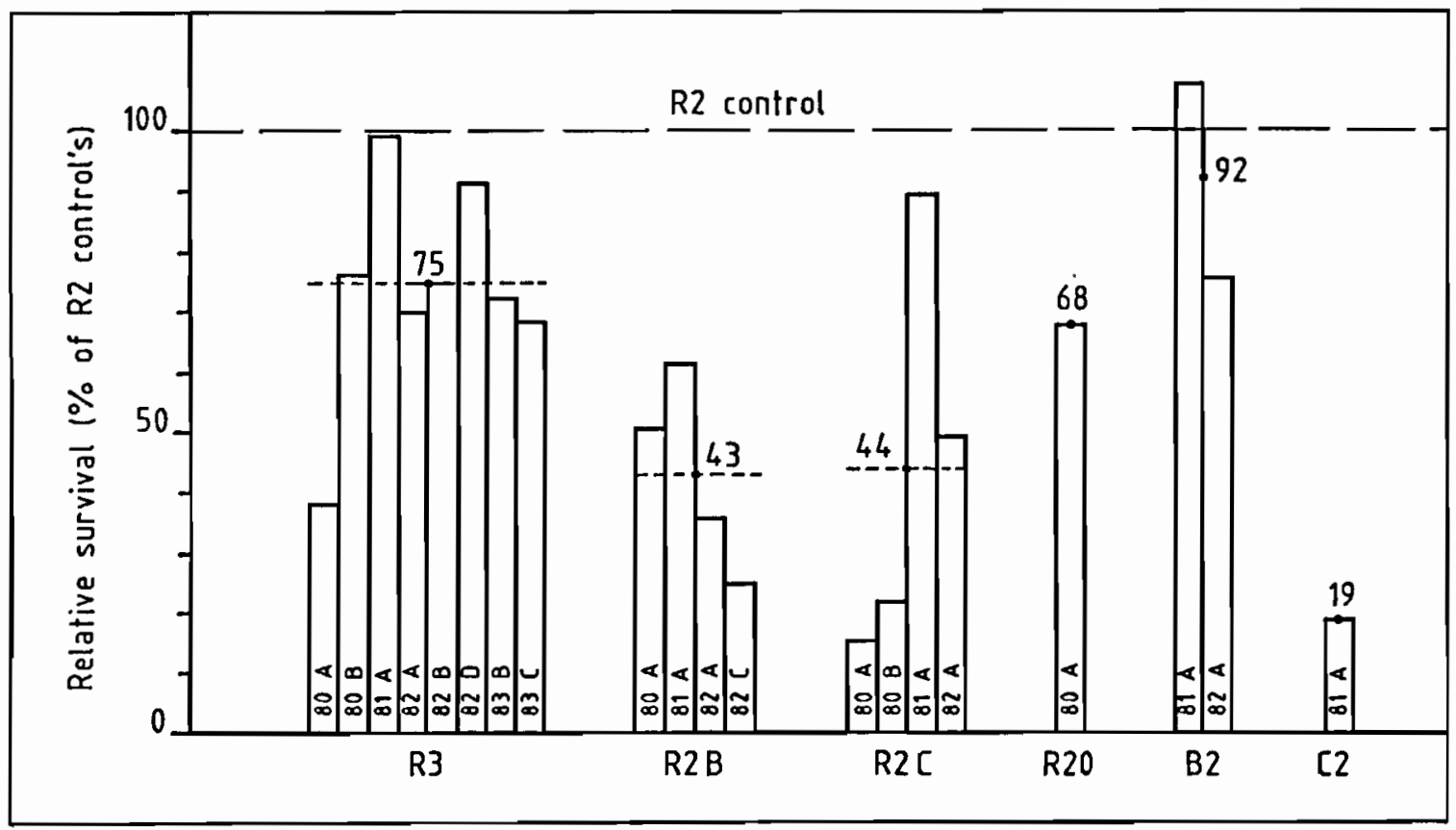

Figure 1. - Early survival (end of $P_{1}$ ) of auto and allotriploids. 
a given population, we could test equality of coefficients of variation as equality of variances, as indicated by Sokal and Rohlf (1981).

\section{RESULTS}

\section{Survival}

Early surtical $\left(\mathbf{P}_{1}\right)$

- Mean performances: At the end of $P_{1}$, early survival in pure species controls was usually high (more than $70 \%$ of ova in both R2 and B2 groups), except for coho salmon $\mathrm{C} 2$, for which low survival was supposed to result from poor egg quality (table 3). Relative survivals rate of the other groups are presented in figure 1 . At that time, all diploid hybrids had died, while relatively high survivals were observed in all triploid groups; autotriploids R3 and rainbow trout $x$ brook trout hybrids cxhibited the best survivals, but all groups were significantly weaker than the diploid rainbow trout control (from 43 to $75 \%$ relative to the control). Mortality occurred regularly from fertilization to the end of $P 1$ and was not typically connected with any particular phase of carly development.

- Variability: Wide variation of mean relative success was detected among the different experiments, especially in R2C groups (see fig. 1-the lowest data observed in $\mathrm{R} 3$ groups was related with miss - handling of eggs after heat shock, and may not be considered as representative of actual variability). Between-female variability was analysed as possible origin of the observed variation from data of experiment $80 \mathrm{~B}$, in which progenies of 4 females were kept separately. Test of homogeneity of survivals in the different genotypes actually revealed important female effect on early survival in all hybrid and triploid groups ( $\mathrm{R} 3, \mathrm{RC}$ and $\mathrm{R} 2 \mathrm{C}$ ), though such an effect could not be detected among the diploid $R 2$ batches (table 4).

\section{Immature period $\left(\mathrm{P}_{2}\right)$}

Daily mortality rates of the different groups are reported in figure 2. Detailed analysis of data (general

Table 4. - Analysis of female effect on survival of the different groups (data of experiment $80 B$ ).

\begin{tabular}{|c|c|c|c|c|c|}
\hline $\begin{array}{l}\text { Group } \\
\text { Stage }\end{array}$ & & R2 & R3 & $R C$ & $\mathrm{R} 2 \mathrm{C}$ \\
\hline \multicolumn{6}{|l|}{ Eyed stage } \\
\hline & $\underset{K}{S}$ & $\begin{array}{l}89.3 \\
7.3 \mathrm{NS}\end{array}$ & $\begin{array}{l}92.0 \\
23.5^{* *}\end{array}$ & $\begin{array}{l}84.0 \\
88.3 * *\end{array}$ & $\begin{array}{l}89.4 \\
31.7^{* *}\end{array}$ \\
\hline \multicolumn{6}{|l|}{ Hatching } \\
\hline & $\underset{\mathbf{K}}{\mathbf{S}}$ & $\begin{array}{l}97.0 \\
3.9 \mathrm{NS}\end{array}$ & $\begin{array}{l}95.0 \\
15.6^{* *}\end{array}$ & $\begin{array}{l}62.0 \\
43.4 * *\end{array}$ & $\begin{array}{l}93.0 \\
21.2^{* 4}\end{array}$ \\
\hline
\end{tabular}

$S=$ survival (in percents).

$K=\chi_{2}$ test ( $3 \mathrm{~d}$ ) for homogeneity between the different females.

* significant for $P<0.05$.

$*+*$ : significant for $\mathrm{P}<0.01$; NS : non significant). test of Newman and Keuls, and restricted paired comparison between $\mathrm{R} 2 \mathrm{C}$ and $\mathrm{C} 2$ ) showed that mortality rate in autotriploids $R 3$ did not differ from $R 2$ control one, but that all triploid hybrids exhibited higher mortality rates than their two parental controls when available.

\section{First maturation cycle and later on $\left(\mathrm{P}_{3}\right)$}

Absolute daily mortality rate in $\mathrm{R} 2$ and $\mathrm{B} 2$ control at that time was about twice as high as it was during the immature period ( fig. 2). Conversely, mortality rate in both autotriploids $\mathrm{R} 3$ and triploid hybrids was reduced, when compared to the previous $P_{2}$ period. Result of these two concurrent evolutions was that R3 groups exhibited at that time better survival than their R2 control (Student's $t$-test significant for $P<0.05)$ and that triploid hybrids did not differ any more from their parental control.

\section{Etolution over the three periods}

Long term evolution of the different groups (summarized in fig. 3) leads to the following conclusions: better survival of autotriploids during the maturation period and later on is enough to balance initial depression relative to the diploid, so that cumulated survivals at 3 years are similar in both groups. On the other hand balancing is not observed in allotriploids, important initial depression, increasing all along the immature period associated with relative survival rate at best equal to the control one contributes to lower final survival in these groups (about half to one third of the parental controls).

\section{Growth performances}

\section{Early' growth ( fig. 4)}

Differences in growth performances of the different groups were detected as soon as the end of $P_{1}$ : autotriploids R3 exhibited slight but significant depression (about $6 \%$ ) when compared with their diploid control. Triploid hybrids, as well as the two paternal species $B 2$ and $C 2$ presented a much more accurate inferiority in weight relative to diploid rainbow trout.

\section{Immature period}

- Mean performances: Initial depression tended to increase all along the following immature period. Anyhow, deviation was kept restricted in autotriploids $R 3$ as their final weight by the end of $P_{2}$ reached $87 \%$ of that of their diploid control ( fig. 5). Conversly, discrepancy was highly emphasized in triploid hybrid groups, that exhibited relative growth performances similar to their paternal control; yet the only available paired comparison (between R2B and B2) indicated that hybrids have had better growth rate than pure patcrnal brown trout control (table 5).

- Within-group tariation: Analysis of cocflicients of variation $\mathrm{CV}$ of the different groups when growth gocs on revealed no difference of within-group 


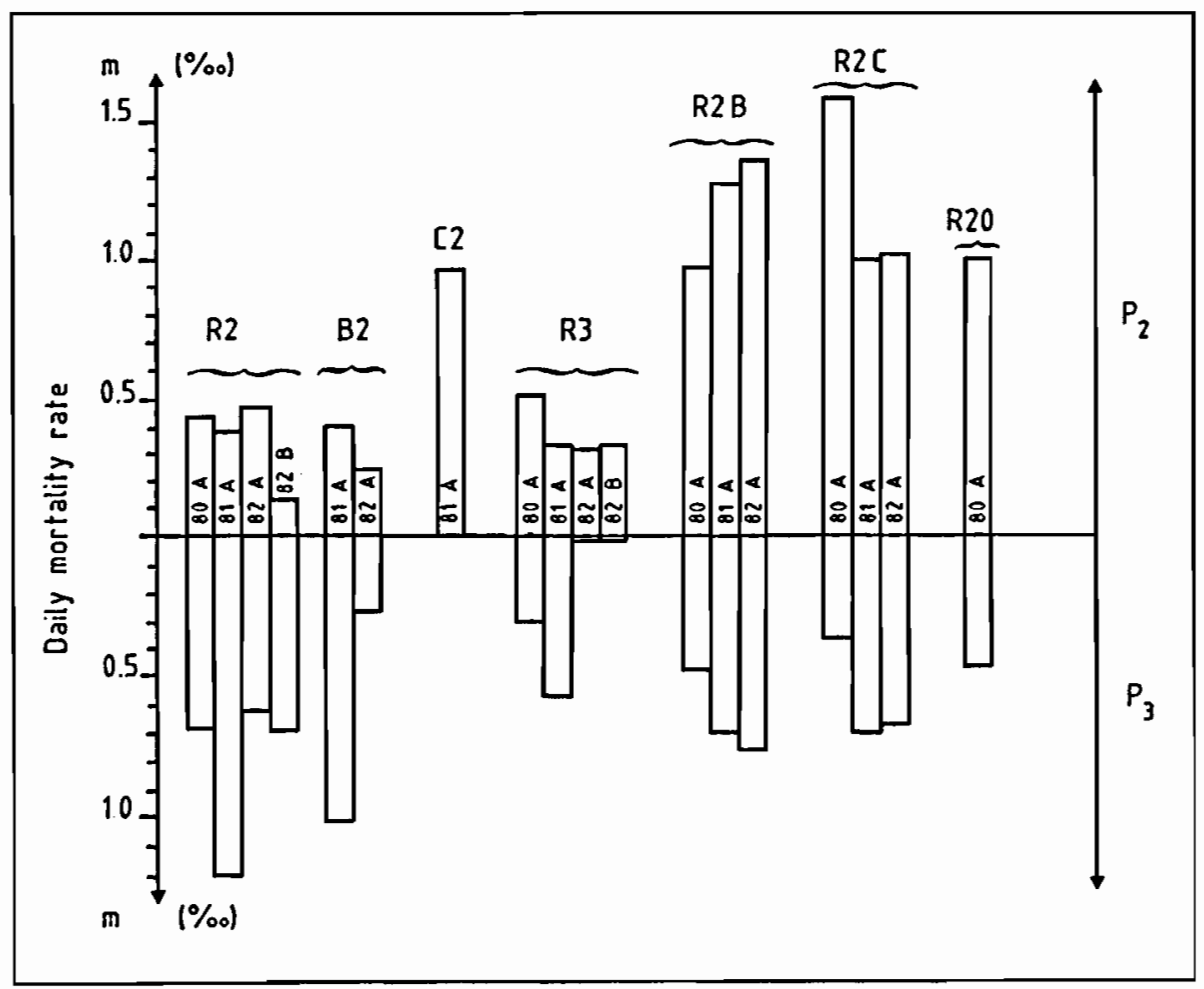

Figure 2. - Daily mortality rate during the immature $\left(P_{2}\right)$ and the maturation $\left(P_{3}\right)$ periods.

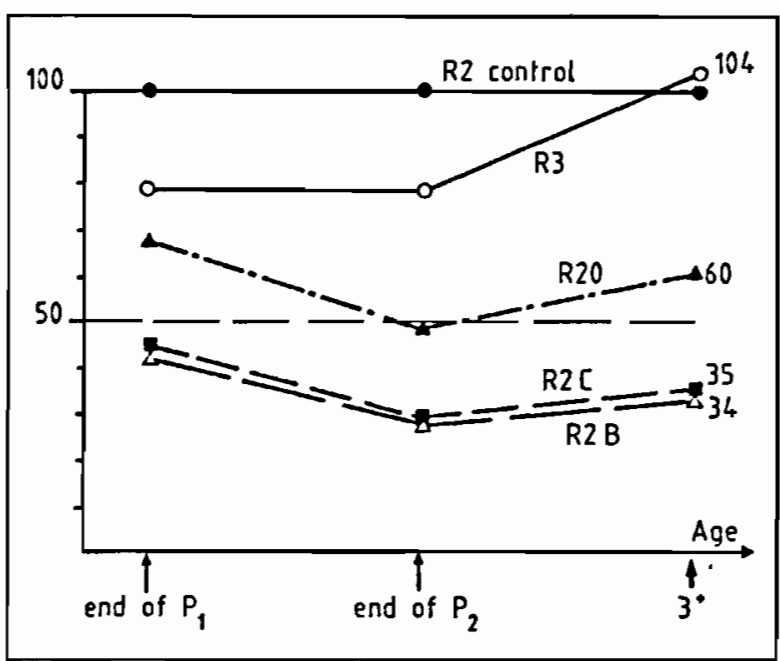

Figure 3. - Evolution of the relative survivals of the different groups over the whole breeding cycle.

variation between parental diploid controls, autotriploids R3 and R2B triploid hybrids. Though tests were not very powerfull, due to low sample sizes (50 data), and therefore usually not significant, R2C triploid hybrids exhibited systematically higher variability than controls.

Extensive measurements in experiment $82 \mathrm{~A}$ confirmed that observation, the only group with higher variability than controls being $\mathrm{R} 2 \mathrm{C}$ (table 6). Simultaneously, coefficient of kurtosis was also particularly high in R2C groups, indicating a tendancy towards bimodal distribution in that particular group (about $9 \%$ of total population heavier than antimode), while others were much more similar to the controls.

\section{Maturation period}

On and after first sexual maturation cycle, diploid rainbow trout females were considered as common reference for comparison of the different groups. Relative weights of the different groups after the two first maturation cycles at $2^{+}$and $3^{+}$are presented in figure 6.

After the first sexual maturation at two years, an important dimorphism was observed between still immature fish and maturing males, weight of which represented 82.0 and $79.5 \%$ of that of immatures in $\mathrm{R} 2$ and B2 controls respectively. The same dimorphism was observed in autotriploids R3: weight of maturing males after the first maturation was only $80.4 \%$ of immature triploid population (table 7 ). However, it was clear that during maturation, R3 triploid males kept higher growth rate than their R2 maturing control. Similarly, triploid sterile females grew faster than maturing diploid females, but did not have significant difference in growth rate with the small proportion of residual immatures of the control population (table 8). 


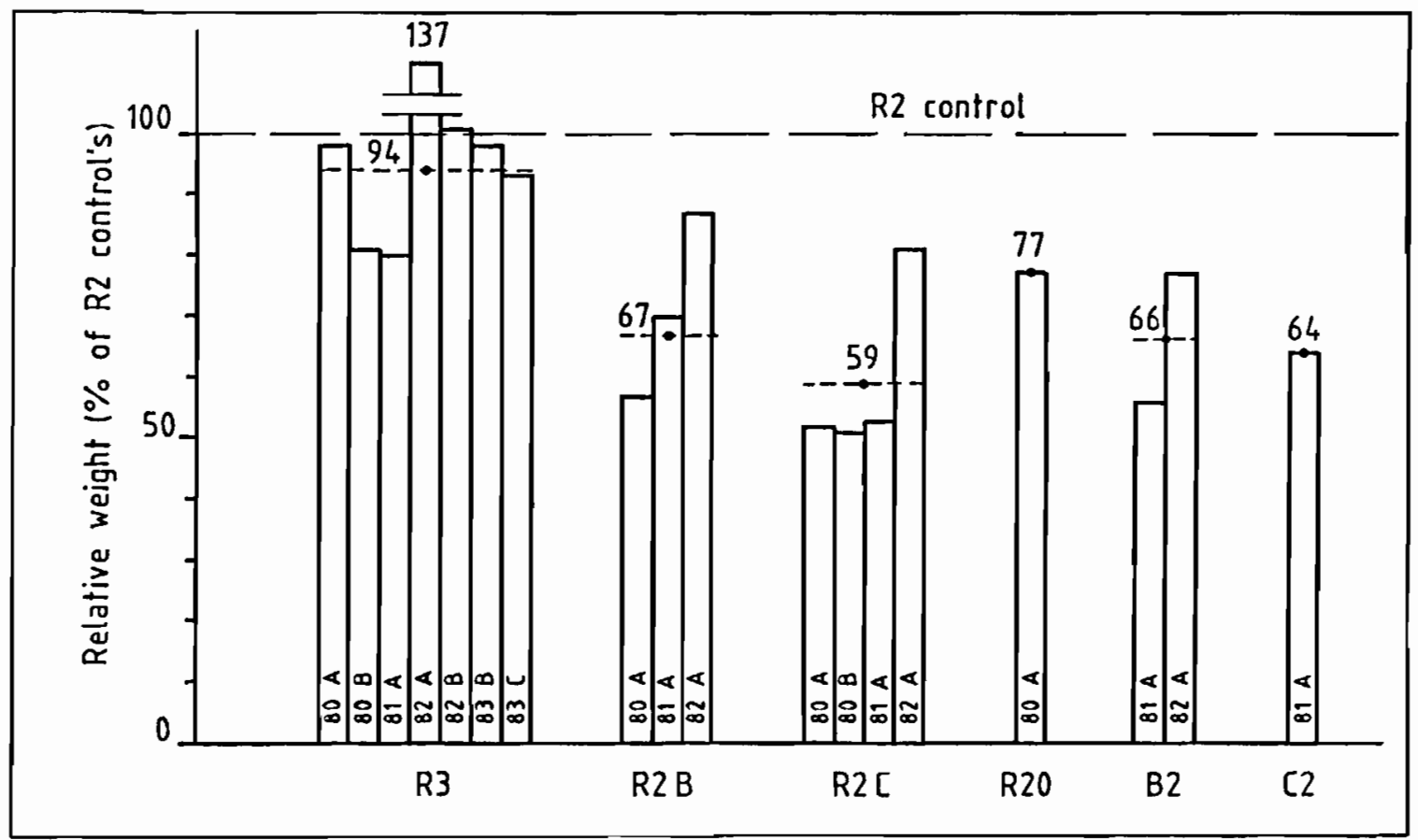

Figure 4. - Early growth (end of $P_{1}$ ) of auto and allotriploids (in $R 3$ groups, weighted mean according to the number of batches in each experiment).

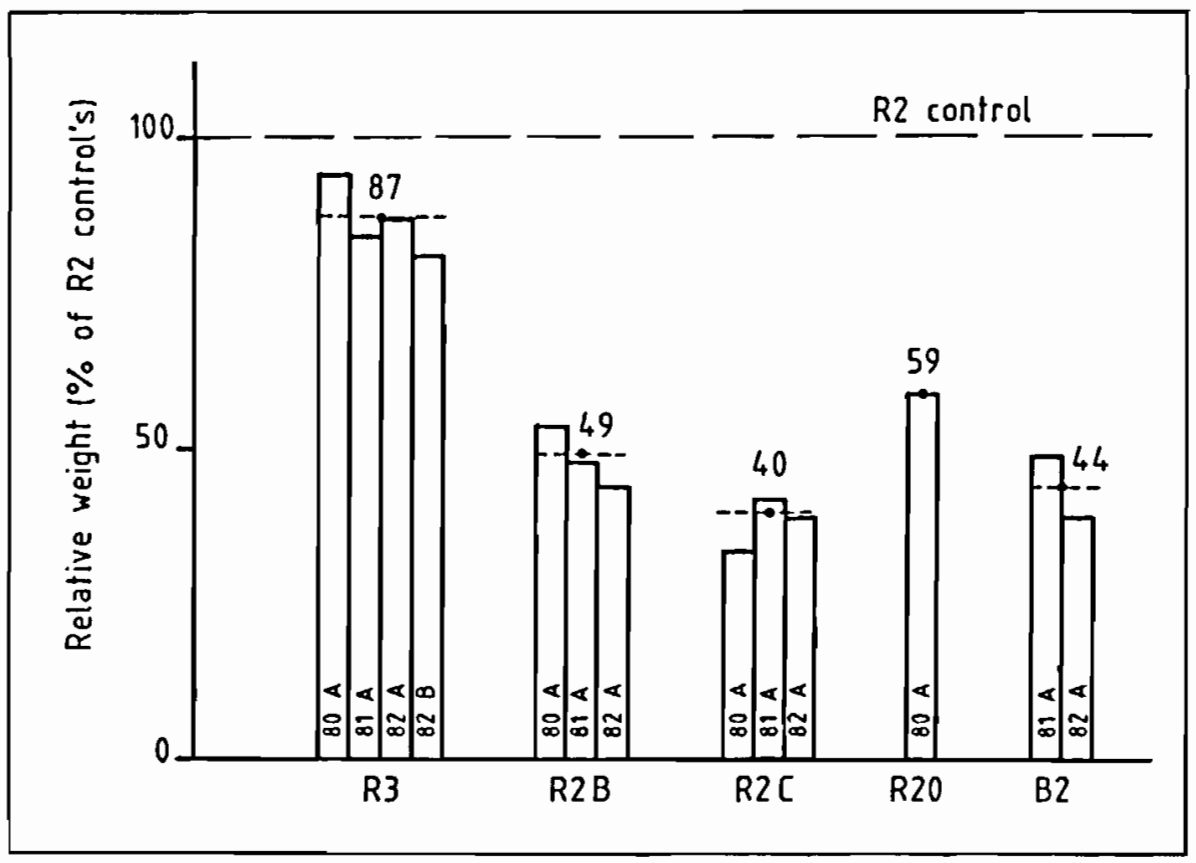

Figure 5. - Weights of the different groups at the end of the immature period $\mathbf{P}_{2}$.

As a result, triploids gradually took advantage from cvery successive maturation cycles. Their relative weight which was $87 \%$ of the diploid one by the end of the immature growth became 104 and $107 \%$ of diploid males and females respectively after the first maturation cycle, and reached 116 and $119 \%$ at $3^{+}$ after the 2nd maturation cycle. Same general trends were observed in triploid hybrids ( fig. 6), despite some specific aspects. Thus, level of dimorphism between mature and immature fish widely depended on hybrids: therefore mature males weighed only 64 and $46,5 \%$ relative to their immature sibs in $\mathrm{F} .2 \mathrm{C}$ 
Table 5. - Analysis of variance for weights at the end of $\mathbf{P 2}$.

\begin{tabular}{|c|c|c|c|c|c|}
\hline & Source of variation & SS & d. f. & MS & $\mathbf{F}$ \\
\hline $\mathbf{R} 2 / \mathbf{R} 3$ & $\begin{array}{c}\text { Group } \\
\text { Experiment } \\
\text { Interaction } \\
\text { Residual }\end{array}$ & $\begin{array}{c}430992 \\
1.03 \times 10^{6} \\
109888 \\
4.99 \times 10^{6}\end{array}$ & $\begin{array}{r}1 \\
3 \\
3 \\
392\end{array}$ & $\begin{array}{r}430992 \\
341752 \\
36629 \\
12739\end{array}$ & $\begin{array}{r}33.83 * * \\
26.83 * * \\
2.87 *\end{array}$ \\
\hline R2/R2B & $\begin{array}{c}\text { Group } \\
\text { Experiment } \\
\text { Interaction } \\
\text { Residual }\end{array}$ & $\begin{array}{c}4.13 \times 10^{6} \\
381192 \\
151696 \\
3.88 \times 10^{6}\end{array}$ & $\begin{array}{r}1 \\
2 \\
2 \\
294\end{array}$ & $\begin{array}{c}4.13 \times 10^{6} \\
190596 \\
75848 \\
13207\end{array}$ & $\begin{array}{r}312.36 * * \\
14.43 * * \\
5.74 * *\end{array}$ \\
\hline $\mathrm{R} 2 / \mathrm{R} 2 \mathrm{C}$ & $\begin{array}{c}\text { Group } \\
\text { Experiment } \\
\text { Interaction } \\
\text { Residual }\end{array}$ & $\begin{array}{c}5.57 \times 10^{6} \\
216848 \\
243676 \\
3.72 \times 10^{6}\end{array}$ & $\begin{array}{r}1 \\
2 \\
2 \\
294\end{array}$ & $\begin{array}{c}5.57 \times 10^{6} \\
108424 \\
121838 \\
12643\end{array}$ & $\begin{array}{r}440.51 * * \\
8.57 * * \\
9.64 * *\end{array}$ \\
\hline $\mathrm{R} 2 / \mathrm{R} 2 \mathrm{O}$ & \multicolumn{5}{|c|}{ Comparison of 2 means Student $(98$ dr $)=8.57^{* 4}$} \\
\hline $\mathrm{R} 2 / \mathrm{B} 2$ & $\begin{array}{c}\text { Group } \\
\text { Experiment } \\
\text { Interaction } \\
\text { Residual }\end{array}$ & $\begin{array}{c}7.00 \times 10^{6} \\
203000 \\
337280 \\
1.97 \times 10^{6}\end{array}$ & $\begin{array}{r}1 \\
2 \\
2 \\
294 \\
\end{array}$ & $\begin{array}{c}7.00 \times 10^{6} \\
101500 \\
168640 \\
6697\end{array}$ & $\begin{array}{r}1045.91 * * \\
15.16^{* *} \\
25.18^{* *}\end{array}$ \\
\hline$B 2 / R 2 B$ & $\begin{array}{c}\text { Group } \\
\text { Experiment } \\
\text { Interaction } \\
\text { Residual }\end{array}$ & $\begin{array}{c}554274 \\
205896 \\
94056 \\
1.69 \times 10^{6}\end{array}$ & $\begin{array}{r}1 \\
2 \\
2 \\
294\end{array}$ & $\begin{array}{r}554274 \\
102948 \\
47028 \\
5745\end{array}$ & $\begin{array}{r}96.48 * * \\
17.92 * * \\
8.18 * *\end{array}$ \\
\hline
\end{tabular}

** : Fisher's (or Student's) test significant for $\mathrm{P}<0.01$ * $^{*}$ : Fisher's test significant for $\mathrm{P}<0.05$.

Table 6. - Within-group variability and distribution of population in experiment $82 \mathrm{~A}$.

\begin{tabular}{|c|c|c|c|c|c|c|}
\hline Group & $n$ & W & SD & $\mathrm{CV}$ & $g_{1}$ & $g_{2}$ \\
\hline R2 & 249 & 17.28 & 7.53 & & 0.577 & -0.342 \\
\hline R3 & & 2.34 & 9.82 & & 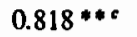 & $0.719 * c$ \\
\hline R2B & 232 & 12.93 & 6.69 & ab & $0.513 * * a d$ & $-0.600 * * c d$ \\
\hline R 2C & 237 & 13.06 & 7.72 & & $1.608 * \cdots$ & $+3.421 * *$ \\
\hline B2 & 235 & & 3.25 & & & \\
\hline \multicolumn{7}{|c|}{$\begin{array}{l}n: \text { number of data. } \\
W: \text { weight (grams). } \\
\text { SD : standard deviation. } \\
C V, g_{1}, g_{2}: \text { see definition in text. } \\
a, b: \text { non significant difference with } \mathrm{R} 2 \text { and } \mathrm{B} 2 \text { controls respecti- } \\
\text { ly }(\mathrm{P}<0.01) \text {. } \\
c, d: \text { significant difference with } \mathrm{R} 2 \text { and } \mathrm{B} 2 \text { respectively }(\mathrm{P}<0.01) \text {. } \\
*: \text { coefficient }\left(g_{1} \text { or } g_{2}\right) \text { significant for } \mathrm{P}<0.05 \text {. } \\
*: \text { coefficient }\left(g_{1} \text { ot } g_{2}\right) \text { significant for } \mathrm{P}<0.01 \text {. }\end{array}$} \\
\hline
\end{tabular}

and $\mathrm{R} 20$ groups respectively, whereas no significant differences could be detected between males and immatures in R2B groups (Student $(48 \mathrm{~d} f)=1.09$; NS) (table 7).

Maturing hybrid males also kept better growth rate than the parental diploid males, so that their relative weight increased with every sexual maturation cycle: R2C males were $49 \%$ of diploid rainbow trout at $2^{+}$ and $78 \%$ at $3^{+}$. Similarly, R2B hybrids were $71 \%$ at $2^{+}$and $82 \%$ at $3^{+}$of rainbow trout control; corresponding ligures were 65.5 and $96 \%$ respectively for the comparison with brown trout males.

Concurrently, relative value of hybrid females also increased relatively to their diploid controls, in even greater proportions as they were completely sterile.
Nevertheless, females hybrids between brook trout and rainbow trout were the only ones to become heavier than the $\mathrm{R} 2$ female control at $2^{+}$.

\section{Evolution over the three periods}

Relative growth of the different groups over a three year long breeding period is summarized in figure 7. In our experimental conditions, rainbow trout was the best growing group all over the immature period. When occurring, maturation involved in most groups clear discrepancies between males and females, the males exhibiting lower growth at that time than their sisters. Anyhow, despite their initial depression, two groups recovered their inferiority relative to the rainbow trout reference: these are pure rainbow trout triploids and rainbow trout $x$ brook trout hybrids, in which females passed beyond the rainbow trout as soon as the first sexual cycle. Next maturation periods went with increase of this relative advantage. All the other groups also show relative improvement after the rainbow control has matured, but they remain lighter within the experimental 3 year long period.

\section{DISCUSSION - CONCLUSION}

\section{Autotriploids}

\section{Surtical}

Reduced survivals in early stages have often been recorded in triploids resulting from application of heat shocks (Chourrout and Quillet, 1982, Lincoln and Hardiman, 1982, Solar et al., 1984, Happe et al., 


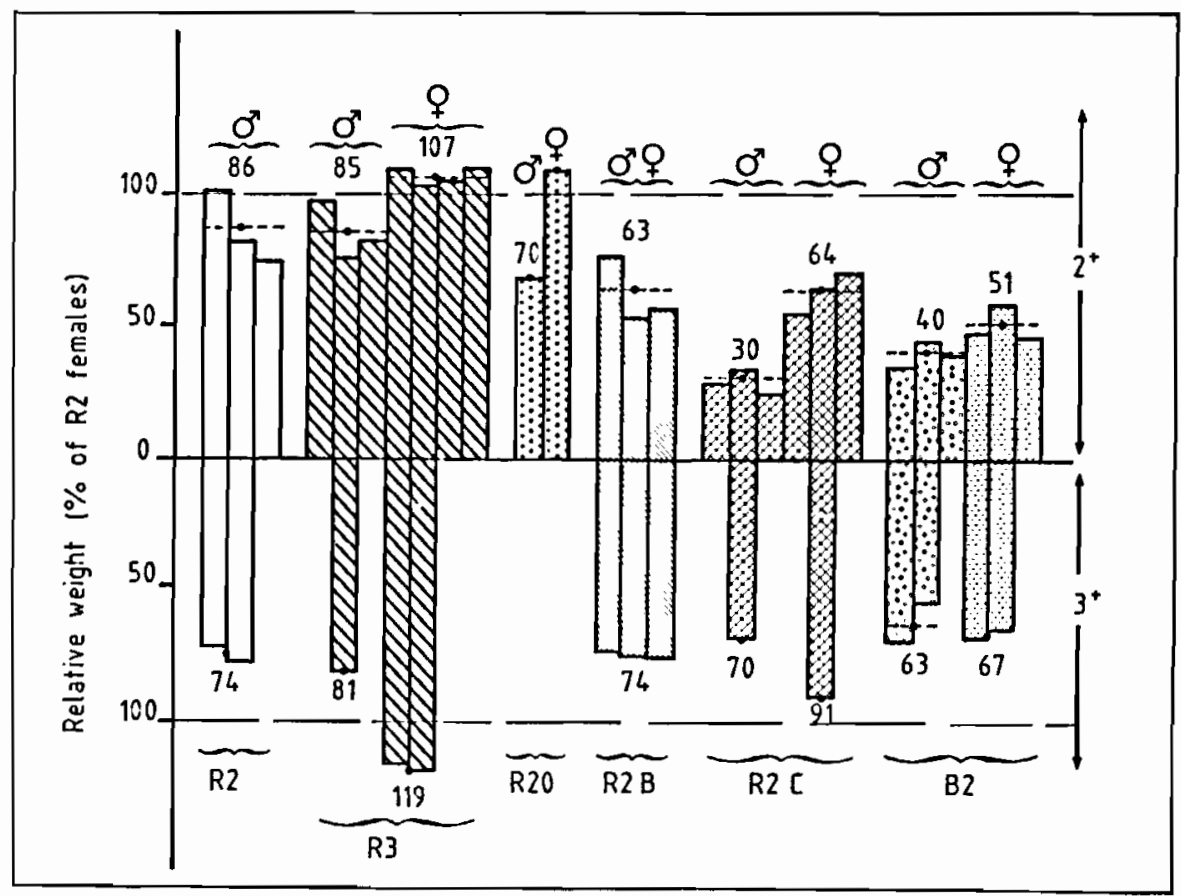

Figure 6. - Weights of the different groups after the first $\left(2^{+}\right)$and the second $\left(3^{+}\right)$sexual maturation cycles.

Table 7. - Sexual dimorphism in the different groups.

\begin{tabular}{|c|c|c|c|c|c|c|c|c|}
\hline & & & $2 b$ & $\mathrm{R} 3 a$ & $\mathrm{R} 2 \mathrm{~B} a$ & $\mathrm{R} 2 \mathrm{C} a$ & $\mathrm{R} 20 \mathrm{a}$ & $a \mathrm{~B} 2 b$ \\
\hline \multirow{4}{*}{$2^{+}$} & $80 \mathrm{~A}$ & 97.9 & $(102.2)$ & 90.4 & 92.4 & 51.9 & 64.3 & 73.1 \\
\hline & $81 \mathrm{~A}$ & 74.6 & $(81.4)$ & 73.1 & - & 51.9 & - & 79.4 \\
\hline & $82 \Lambda$ & 73.5 & (74.4) & 78.7 & $143.1^{c}$ & 35.6 & - & 85.9 \\
\hline & Mean & $82.0^{\circ}$ & (86.0) & $80.4^{* *}$ & $92.4 \mathrm{NS}$ & $46.5 * *$ & $64.3^{* *}$ & $79.5^{* *}$ \\
\hline \multirow[b]{2}{*}{$3^{+}$} & $80 A$ & & $(71.2)$ & - & - & - & - & $(101.0)$ \\
\hline & $81 \mathrm{~A}$ & & (77.7) & 67.4 & 99.1 & 76.5 & - & (88.1) \\
\hline
\end{tabular}

$a:$ relative value of males over immatures. $b$ : relative value of males over mature females. $c:$ only 2 males are recorded.

Table 8. - Comparison of growth rates during sexual maturation in diploid and triploid rainbow trout.

\begin{tabular}{|c|c|c|c|c|c|}
\hline & $\begin{array}{c}\text { Source } \\
\text { of } \\
\text { variation }\end{array}$ & SS & d. f. & MS & $\mathbf{F}$ \\
\hline 3 $\mathrm{R} 2 / 3 \mathrm{R} 3$ & $\begin{array}{c}\text { Group } \\
\text { Experiment } \\
\text { Residual }\end{array}$ & $\begin{array}{l}1.13 \times 10^{-2} \\
3.43 \times 10^{-2} \\
7.95 \times 10^{-3}\end{array}$ & $\begin{array}{l}1 \\
5 \\
5\end{array}$ & $\begin{array}{l}1.13 \times 10^{-2} \\
6.86 \times 10^{-3} \\
1.59 \times 10^{-3}\end{array}$ & $\begin{array}{l}7.10^{*} \\
4.31 \mathrm{NS}\end{array}$ \\
\hline q R2/7 R3 & $\begin{array}{c}\text { Group } \\
\text { Experiment } \\
\text { Residual }\end{array}$ & $\begin{array}{l}4.91 \times 10^{-2} \\
1.16 \times 10^{-1} \\
2.82 \times 10^{-2}\end{array}$ & $\begin{array}{l}1 \\
6 \\
6\end{array}$ & $\begin{array}{l}4.91 \times 10^{-2} \\
1.93 \times 10^{-2} \\
4.71 \times 10^{-3}\end{array}$ & $\begin{array}{c}10.43^{*} \\
4.09 \mathrm{NS}\end{array}$ \\
\hline $\operatorname{Im} . \mathrm{R} 2 / \operatorname{Im} . \mathrm{R} 3\left(^{\circ}\right)$ & $\begin{array}{c}\text { Group } \\
\text { Experiment } \\
\text { Residual }\end{array}$ & $\begin{array}{l}1.55 \times 10^{-2} \\
1.81 \times 10^{-1} \\
3.69 \times 10^{-2}\end{array}$ & $\begin{array}{l}1 \\
8 \\
8\end{array}$ & $\begin{array}{l}1.55 \times 10^{-2} \\
2.26 \times 10^{-2} \\
4.61 \times 10^{-3}\end{array}$ & $\begin{array}{l}3.36 \mathrm{NS} \\
4.91\end{array}$ \\
\hline
\end{tabular}

$\left.{ }^{e}\right)$ Immature fish at 2 years. ${ }^{*}$ : Fisher significant for $\mathbf{P}<0.05$. 


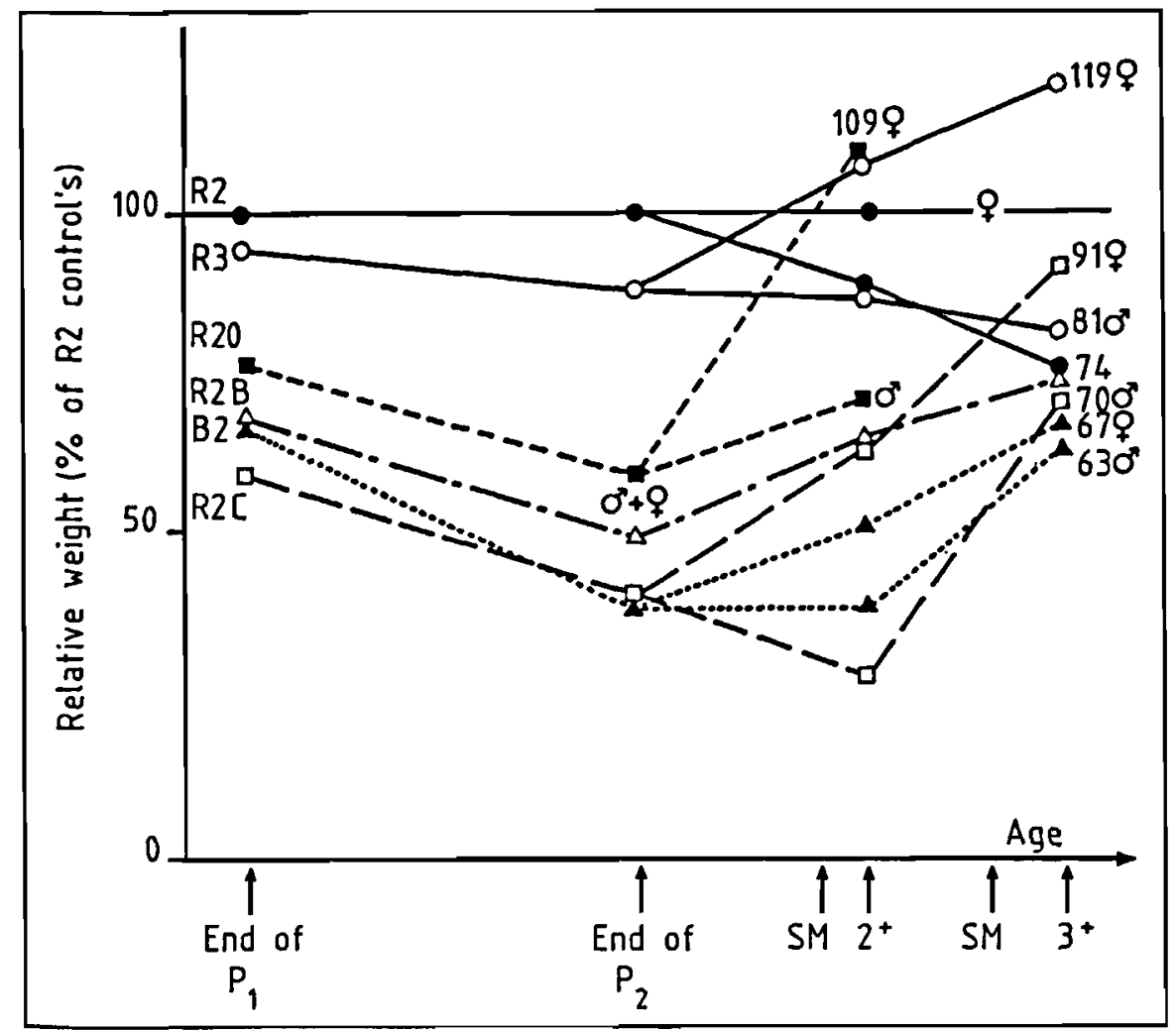

Figure 7. - Evolution of the relative weights of the different groups over the whole breeding cycle.

in press, in rainbow trout; Scheerer and Thorgaard, 1983, in brown trout; Benfey and Sutterlin, 1984, Johnstone, 1985 in Atlantic salmon). Lower survivals may result from persistent deleterious effect of thermal shock on egg quality (i. e. integrity of yolk component). One indication is that eggs appear particularly susceptible to handling at the end of the thermal treatment. Nevertheless, it does not seem that use of other treatments (i. e. pressure shocks) improves survival.

One possible approach of treatment effect is comparison of such triploids with second generation triploids, obtained by mating diploid females and tetraploid males (Chourrout et al., 1986), as production of the latter does not involve any treatment of the ova. There are several results indicating that second generation triploids may have better survival than heat-shock ones (Chourrout et al., 1986), at least in very early stages (yolk resorption, Blanc et al., 1987).

Later on, however, no difference was detected between triploids and their control all over the immature period. These results are similar with several data available in the literature (Gervai et al., 1980 in carp; Lincoln and Hardiman, 1982, in rainbow trout; Suzuki et al., 1985, in the cyprinid loach) but are not totally consistent with other observations that point out decreases in the frequency of triploids as fish grow old in populations initially containing diploids and triploids (Thorgaard et al., 1982, in rainbow trout; Utter et al., 1983, in coho salmon).
Yet, previous results were generally recorded under so called "optimal" rearing conditions, but it must also be underlined that, when kept under more restrictive conditions, triploids may eventually exhibit greater weakness than diploids: Johnson et al. (1986) once reported special susceptibility of triploid coho salmon to the stress of seawater challenge, Quillet et al. (1987) also recorded higher mortality in triploid rainbow trout than in diploids during summer time in seawater farming on French coast. On another hand, Dorson and Chevassus $(1985 a, 1985 b)$ did not detect differential mortalities in diploid and triploid rainbow trout after challenge with IPN and VSH virus. Despite disputable results, one can not exclude the possibility that triploids may be weaker than diploids in some conditions, though that should not be a nuisance in most cases.

\section{Growth}

Growth of triploids follows the same general trend than survival, triploids being smaller than diploids up to the onset of sexual maturation, and getting heavier later on. If our results are somewhat variable from an experiment to another concerning early stages (relative value of triploids ranging from 80 to $137 \%$ at the end of $P_{1}$ ), depression by the end of $P_{2}$ is well established from our data. Such an observation is in agreement with many results available in literature: most of the authors find that triploids grow less than 
diploids, or at best, as much as them (see table 9), though, in most cases, few information is available concerning emergence of the discrepancy if any. Nevertheless, several arguments indicate that origin of the depression should not lie in early embryonic and larval development; indeed, measurements by
Happe et al. (in press) and Quillet et al. (in press) establish that triploids hatch slightly before diploids: triploids are therefore most likely to take relative developmental advance at that time rather than delay.

Similarly, observations of Oliva-Teles and Kaushik (1987) on embryonic metabolism and of Happe et al.

Table 9. - Comparison of growth of diploids and triploids in different experiments.

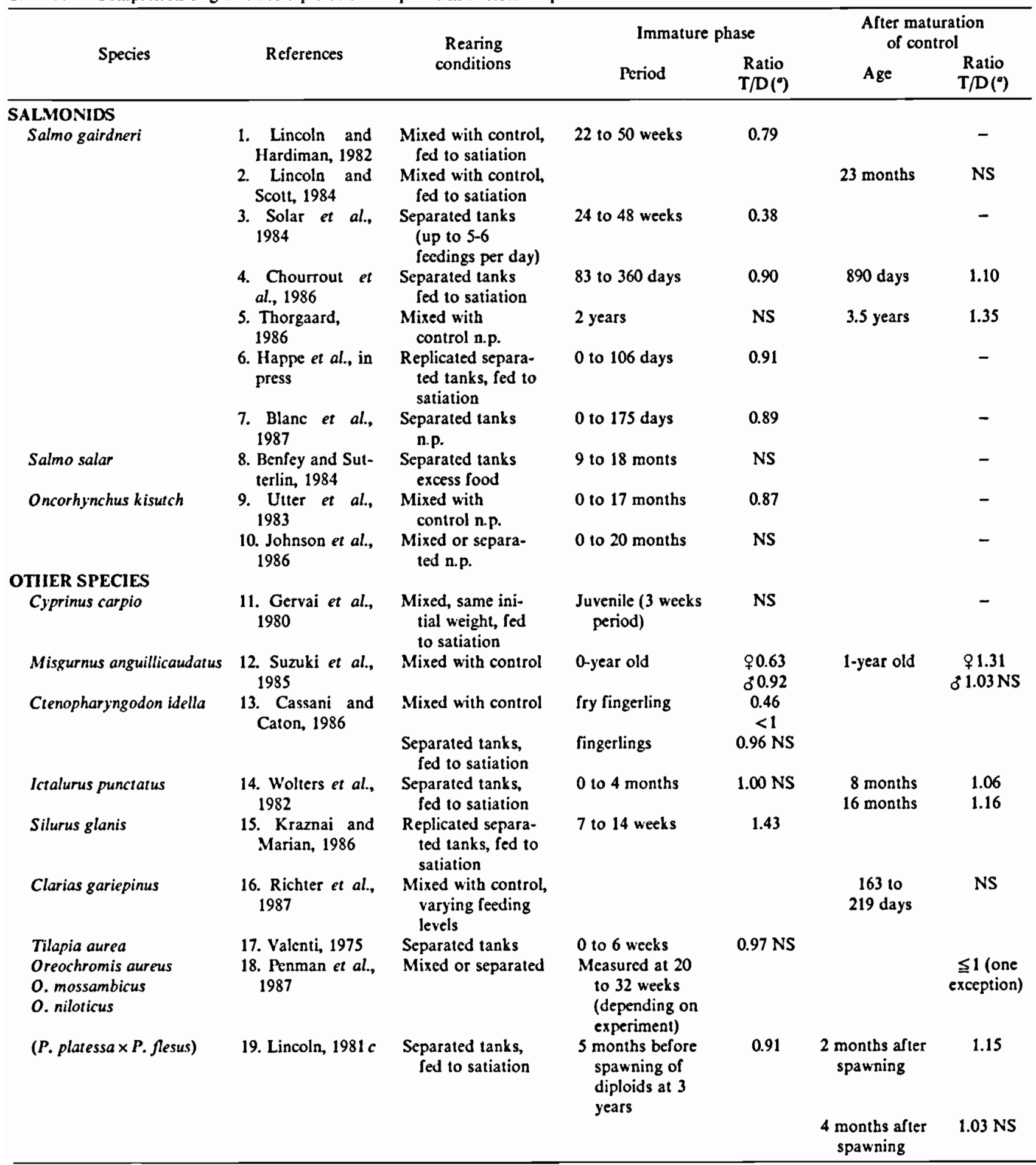


(in press) on larval growth during yolk resorption are consistent one with the other, and indicate no difference in utilization of endogenous reserves between diploid and triploid larvac.

It seems from experiment by Happe et al. (in press) that emergence of the discrepancy goes with introduction of exogenous feed at swim up; this suggests that differences either in feeding behavior or (and) in long term metabolism are involved.

Results of Cassini and Caton (1986) on triploid grass carps reared in various conditions (density, feeding level, competition with diploids or no) comfort such hypotheses. Similarly, Bricout et al. (unpublished data) showed that keeping triploids rainbow trout fingerlings in separated tanks instead of mixing them with diploids, as well as changing rate of feeding could modify the relative ranking of the two groups for both growth rate and food conversion efficiency.

So, differences in rearing conditions may contribute to the inconsistency of the above cited results on relative growth of triploids. More over, it secms that restrictive conditions for survival previously discussed may also emphasize the tendancy of triploids to grow slower than diploids (Cassini and Caton, 1986; Johnson et al., 1986; Quillet ct al., 1987).

On the other hand, relative superiority of triploids during the onset of sexual maturation is also generally recorded, though absolute gain is variable (table 9), and can be interpreted as a direct consequence of sterility of triploids, which invest few or no for gonadal growth and keep good somatic growth rate during this period. As a matter of fact, triploid females, that were completely sterile, displayed the greatest advantage during this period in our experiment. Nevertheless, gonadal development is sometimes observed in triploid females (Penman et al., 1987 in tilapia $O$. aureus).

Comparing diploid and triploid plaice $\times$ flounder femalc hybrids, Lincoln (1981) described rapid growth in diploids following spawning, so that they compensated their loss in weight. We have no data to confirm such an evolution, but even if similar phenomenon occurred in our case, it was not enough to overcome the relative loss of diploids, as we observed an increase of relative advantage of triploids after several maturation cycles.

\section{Allotriploids}

\section{Surtival}

All three hybrids we have studied in the present paper are highly inviable when diploid (Chevassus, 1979). Despite noticeable increase of viability by triploidization tratment (Chevassus et al., 1983; Scheerer and Thorgaard, 1983), these animals remain weaker than the parental controls all over the immaturc period. No specific discase was identified as causal agent of the death of lish, and mortality was regularly distributed in time. At the onset of sexual maturation, triploid hybrids display same evolution of gonads than pure species triploids and are not very affected by maturation. Nevertheless, this is not sufficient to overcome their general weakness, and they just equalize maturing controls at that time.

Another trait of triploid hybrids is the important variability of success of hybridization. Large variability of survival rates is a general feature in diploid interspecific crosses (Ayles, 1974; Chevassus and Petit, 1975; Blanc and Chevassus, 1979) and it seems that female effect could be a major cause of this variability (Blanc and Poisson, 1983). The same phenomenon is observed in triploid hybrids. In both cases however, survival of hybrids is not correlated with survival of monospecific crosses, and that will make selection for better survival (if desired) much more difficult to manage.

\section{Growth}

Two main factors are likely to influence growth rate of triploid hybrids that are (1): triploid state previously discussed in the case of triploid rainbow trout, and (2): hybrid state and potential effect of genic balance between the genomes of the different species. Additive inheritance in interspecific hybrids was demonstrated by Purdom (1972) in diploid hybrids, triploid hybrids and the back-cross between plaice and flounder for some characteristics as number of vertebrae or larval pigmentation.

Our data indicate that growth of triploid hybrids is influenced by both parental species. This can be stated in the case of rainbow trout $x$ brown trout hybrid, for which both parental species are available. Similarly, though data on pure brook trout are not available in our experiments, hybrid involving that species exhibit good growth, which is consistent with previous works on this species and its hybrids (Refstic and Gjedrem, 1975; Sutterlin et al., 1977).

Nevertheless, caution must be kept when considering values of $\mathrm{R} 2 \mathrm{C}$ hybrids in our study, because both survival and growth of coho salmon are extremely poor in our experimental conditions, and certainly not representative of actual potential of this species.

No clear effect of triploidy on within-group variability during immature growth is detected from our data, but in rainbow trout $\times$ coho salmon hybrids. Whether this variability results from only paternal inheritance or is emphasized because of triploid status remains questionnable, due to lack of reliable coho salmon control in our experimental conditions. Bimodal distribution, associated with this high variability, may also be related to partial smoltification of hybrids, but further observations will be necessary to conclude on the particular point.

$\Lambda t$ last, reduction of growth depression of hybrids relative to rainbow trout control during the onset of maturation can also be interpreted as the main consequence of sterility of those groups. Maintenance of good growth rate of triploid females before and 
during spawning had already been observed by Lincoln (1981) in llatfish hybrids. Yet in our conditions, hybrid involving brook trout is the only one that passed beyond rainbow control at $2^{+}$.

\section{Practical interest of triploids}

Practical interest of triploids will depend on economical consequence of their characteristics relative to diploid populations in specific breeding schemes. Some authors have concluded from analysis of their data that triploidy would not confer any particular advantage for fish farming (Lincoln, $1981 \mathrm{c}$ in flatfish; Penman et al., 1986 in tilapia; Richter et al., 1986) except for body composition (gutted weight, muscle composition). We provide here preliminary calculations from our data in order to compare the different groups in term of total production they allow, taking both survival and growth into account (table 10). This clearly indicates that triploidy confers a benefit as soon as production of large animals (implying rearing fish over at least one maturation cycle) is planned that should certainly be enhanced if economical costs of production were also taken into account: for instance, most of the mortality in triploids occurs at carly stages, while late mortality in diploids affects animals with high individual value; similarly, Wolters et al. (1982) recorded better feed conversion in triploid tilapia than in maturing diploids. Time when triploids become superior to their control will depends on several factors as the age at sexual maturation in the local control, the extend to which growth and survival are reduced by maturation.

Yet, in some specific cases (disease attack for instance), relative superiority of triploid hybrids may also raise carlier in the breeding cycle. Anyhow, rearing all female triploid populations should be recommanded as a complementary technique, to take full advantage of their complete sterility. Beside an absolute increase of biomass production, this could also allow a distribution of sales all over the year, both survival and growth into account (table (0). I his clearly indicates that triploidy confers a benelit as soon as production of large animals (implying rearing fish over at least one maturation cycle) is planned that should certainly be enhanced if economical costs of production were also taken into account: for ins-
Table 10. - Productiveness of the different groups in terms of total biomass (same initial number of fry in every case).

\begin{tabular}{|c|c|c|c|c|}
\hline & \multicolumn{4}{|c|}{ Total biomass $\left({ }^{a}\right)$} \\
\hline & & $1^{+}$ & $2^{+}$ & $3^{+}$ \\
\hline \multirow{2}{*}{ R2 } & 3 & \multirow{2}{*}{100} & 86 & 74 \\
\hline & 9 & & 100 & 100 \\
\hline \multirow[b]{2}{*}{ R3 } & 8 & \multirow[b]{2}{*}{85} & 97 & 93 \\
\hline & $q$ & & 122 & 137 \\
\hline \multirow[b]{2}{*}{ R2B } & 3 & \multirow[b]{2}{*}{33} & \multirow[b]{2}{*}{40} & \multirow[b]{2}{*}{65} \\
\hline & $q$ & & & \\
\hline \multirow[b]{2}{*}{$\mathrm{R} 2 \mathrm{C}$} & $\sigma^{\prime}$ & \multirow[b]{2}{*}{28} & 22 & 66 \\
\hline & $q$ & & & 77 \\
\hline \multirow[b]{2}{*}{ R2O } & $\sigma^{*}$ & \multirow[b]{2}{*}{44} & 70 & \multirow[b]{2}{*}{ - } \\
\hline & q & & 110 & \\
\hline \multirow{2}{*}{ B2 } & $\overline{0}$ & \multirow{2}{*}{42} & 48 & 69 \\
\hline & $q$ & & 61 & 73 \\
\hline
\end{tabular}

(") Relative production, taking both growth and survival into account.

tance, most of the mortality in triploids occurs at early stages, while late mortality in diploids affects animals with high individual value; similarly, Wolters et al. (1982) recorded better feed conversion in triploid tilapia than in maturing diploids. Time when triploids become superior to their control will depends on several factors as the age at sexual maturation in the local control, the extend to which growth and survival are reduced by maturation.

Yet, in some specilic cases (disease attack for instance), relative superiority of triploid hybrids may also raise carlier in the breeding cycle. Anyhow, rearing all female triploid populations should be recommanded as a complementary technique, to take full advantage of their complete sterility. Beside an absolute increase of biomass production, this could also allow a distribution of sales all over the year, and result in a more flexible management of livestock.

\section{Acknonledgements}

This work was supported by IFREMER grants (rel.: CNEXO 81/2476, 82/2680 Y, 83/2991 Y and IFREMIER 84/3265 Y). We wish to thank G. Burger, A. Devaux, J. P. Hiseux and Huguette Poisson for their technical assistance, and Geneviève Servais for typing the manuscript. 


\section{REFERENCES}

Arai K, 1984. Developmental genetic studies on salmonids: morphogenesis, isozyme phenotypes and chromosomes in hybrid embryos. Reprinted from Memoirs of the Faculty of Fïsheries Hokkaido Unicersity, 31, 1-94.

Ayles G. B., 1974, Relative importance of additive genetic and maternal sources of variation in early survival of young splake hybrids (Salcelinus fontinalis, $S$. namaj(ush). J. Fish. Res. Bd Can., 31, 1499-1502.

Benfey T., 1985. Maturation in triploid atlantic salmon (Salmo salar L.). Oral communication; Second International Symposium on "Genetics in Aquaculture"; June 23-28th, Davis, USA (unpublished).

Benfey T. J., A. M. Sutterlin, 1984. Grotwth and gonadal development in triploid landlocked Atlantic salmon (Salmo salar). Can. J. Fish. Aquat. Sci., 41, 1387-1392.

Billard R., 1977. Utilisation d'un système tris-glycocolle pour tamponner le dilueur d'insémination pour truite. Bull. Fr. Pisc., 264, 102-112.

Blanc J. M., B. Chevassus, 1979. Interspecific hybridization of salmonid fish. I. Hatching and survival up to the 15 th day after hatching in F1 generation hybrids. Aquaculture, 18, 21-34.

Blanc J. M., H. Poisson, 1983. Parental sources of variation in hatching and early survival rates of Salmo trutta female and Salcelinus fontinalis male hybrid. Aquaculture, 32, 115-122.

Blanc J. M., D. Chourrout, F. Krieg, 1987. Evolution of juvenile rainbow trout survival and growth in halfsib families from diploid and tetraploid sires. Aquaculture, 65 , in press.

Cassani J. R., W. E. Caton, 1986. Growth comparisons of diploid and triploid grass carp under varying conditions. Progres. Fïsh-Cult., 48, 184-187.

Chevassus B., 1976. Variabilité et héritabilité des performances de croissance chez la truite arc-en-ciel (Salmo gairdneri). Ann. Génét. Sél. anim., 8, 273-283.

- 1979. Hybridization in Salmonids: Results and perspectives. Aquaculture, 17, 113-128.

- 1987. Caractéristiques et performances des lignées uniparentales et des polyploïdes chez les poissons d'eau froide. In : Proc. World Symp. on selection, hybridization and genelic engineering in aquaculture of fish and shellfish for consumption and stocking. Bordeaux, France, 27-30 May 1986; Berlin, K. Tiews, Vol. II, 145-161.

Chevassus B., R. Guyomard, D. Chourrout, E. Quillet, 1983. Production of viable hybrids in salmonids by triploidization. Génét., Sél., Evol., 15, 519-532.

Chevassus B., J. Petit, 1975. Hybridation artificielle entre la Truite Arc-en-ciel (Salmo gairdneri Richardson) et le Saumon coho (Oncorhynchus kisutch Walbaum). Ann. Génét. Sél. anim., 7, 1-11.

Chevassus B., E. Quillet, D. Chourrout, 1985. La production de truites stériles par voie génétique. La pisciculture française, 78, 10-19.

Chourrout D., 1980. Thermal induction of diploid gynogenesis and triploidy in the eggs of the rainbow trout, Salmo gairdneri R. Reprod. Nutr. Dételop., 20, 727-733.
- 1986. Techniques of chromosome manipulation in rainbow trout: a new evaluation with karyology. Theor. Appl. Genet., 72, 627-632.

- 1987. Genetic manipulations in fish: review of methods. In : Proc. World Symp. on selection, hybridization and genetic engineering in aquaculture of fish and shellfish for consumption and stocking, Bordeaux, France, 27-30 May 1986, Berlin : K. Tiews, Vol. II, 111-126.

Chourrout D., E. Quillet, 1982. Induced gynogenesis in the rainbow trout: sex and survival of progenies. Production of all triploid populations. Theor. Appl. Genet., 63, 201205.

Chourrout D., B. Chevassus, F. Krieg, A. Happe, G. Burger, P. Renard, 1986. Production of second generation triploid and tetraploid rainbow trout by mating tetraploid males and diploid females. Potential of tetraploid fish. Theor. Appl. Genet, 72, 193-206.

Dorson M., B. Chevassus, $1985 a$. Etude de la réceptivité d'hybrides triploïdes truite arc-en-ciel $\times$ saumon coho à la nécrose pancréatique infectieuse et à la septicémie hémorragique virale. Bull. Fr. Pêche Piscic., 296, 29-34.

- $1985 \mathrm{~b}$. Resistance of triploid rainbow trout and brook trout hybrids to viral haemorragic septiceamia. Poster presented at 2nd Symposium of European Association of fish pathologists, September, Montpellier, France.

Gervai J., S. Peter, A. Nagy, L. Hurvath, V. Csanyi, 1980. Induced triploidy in carp, Cyprinus carpio L. J. Fish. Biol., 17, 667-671.

Happe A., E. Quillet, B. Chevassus. Early life history of triploid rainbow trout (Salmo gairdneri Richardson) up to 4 months. Aquaculture, in press.

Johnson O. W., W. W. Dickhoff, F. M. Utter, 1986. Comparative growth and development of diploid and triploid coho salmon, Oncorhynchus kisutch. Aquaculture, 57, 329-336.

Johnstone R., 1985. Induction of triploidy in Atlantic salmon by heat shock. Aquaculture, 49, 133-139.

Kraznai Z., T. Marian, 1986. Shock-induced triploidy and its effect on growth and gonad development of the Europcan catfish, Silurus glanis L. J. Fish. Biol., 29, 519-527.

Lincoln R. F., 1981 a. Sexual maturation in triploid male plaice (Pleuronectes platessa) and plaice $\times$ flounder (Plactichthys flesus) hybrids. J. Fish. Biol., 19, 415-426.

- 1981 b. Sexual maturation in female triploid plaice (Pleuronectes platessa) and plaice $\times$ flounder (Platichthys flesus) hybrids. J. Fish. Biol., 19, 499-507.

- $1981 \mathrm{c}$. The growth of (emale diploid and triploid plaice (Pleuronectes platessa) $\times$ flounder (Platichthys flesus) hybrids over the spawning season. Aquaculture, 25, 259268.

Lincoln R. F., P. A. Hardiman, 1982. The production and growth of female diploid and triploid rainbow trout. Oral communication; International Symposium on Genetics in Aquaculture. 29 March-2 A pril. Univ. College, Galway, Ireland (unpublished).

Lincoln R. F., A. P. Scott, 1983. Production of all-female triploid rainbow trout. Aquaculture, 30, 375-380.

- 1984. Sexual maturation in triploid rainbow trout Salmo gairdneri Richardson. J. Fish. Biol., 25, 385-392.

Oliva-Teles A., S. J. Kaushik, 1987. Nitrogen and energy metabolism during the early development of diploid and 
triploid rainbow trout (Salmo gairdneri R.). Comp. Biochem. Physiol., 87A, 157-160.

Parsons J. E., R. Busch, O. Thorgaard, P. Scheerer, 1986. Increased resistance of triploid rainbow trout coho salmon hybrids to infectious hematopoietic necrosis virus. Aquaculture, 57, 337-343.

Penman D. J., D. O. F. Skibinski, J. A. Beardmore, 1987. Survival, growth rate and maturity in triploid tilapia. In : Proc. World Symp. on sclection, hybridization and genetic engineering in aquaculture of fish and shellish for consumption and stocking: Bordeaux, France, 27-30 May, Berlin : K. Tiews, in press.

Purdom C. E., 1972. Induced polyploidy in plaice (Pleuronectes platessa) and its hybrid with the flounder (Platichthys flesus). Ileredity, 29, 11-24.

Purdom C. E., 1983. Genetic engineering by the manipulation of chromosomes. Aquaculture, 33, 287-300.

Quillet E., 1986. Contribution à l'ćtude de la triploïdie induite chez les salmonidés : conséquences sur les caractéristiques zootechniques. Thèse de Docteur-Ingénieur. Institut National Agronomique, Paris, 126 p.

Quillet E., B. Chevassus, A. Devaux. Timing and duration of hatching in gynogenetic, triploid, tetraploid, and hybrid progenies in rainbow trout. Génét. Sél. Evol., in press.

Quillet E., B. Chevassus, F. Krieg, 1987. Characterization of auto and allo-triploids for rearing in seawater cages. In : Proc. World Symp. on selection, hybridization and genetic enginecring in aquaculture of fish and shellfish for consumption and stocking, Bordeaux, France, 27 30 May, Berlin, K. Tiews, Vol. II, 239-252.

Refstie T., T. Gjedrem, 1975. Hybrids between Salmonidae species. Hatchability and growth rate in the fresh water period. Aquaculture, 6, 333-342.

Richter C. C. J., A. M. Henken, E. H. Eding, J. H. Van Doesum, P. de Boer, 1987. Induction of triploidy by cold-shocking eggs and performance of triploids in the african catlish, Clarius gariepinus (Burchell, 1822). In : Proc. World Symp. on sclection, hybridization and genetic engineering in aquaculture of fish and shellfish for consumption and stocking, Bordeaux, France, 2730 May, Berlin : K. Tiews, in press.

Schecrer P. D., G. H. Thorgaard, 1983. Increased survival in salmonid hybrids by induced triploidy. Can. J. Fish. Aquat. Sci., 40, 2040-2044.

Scherrer B., 1984. Biostatistique. Gaëtan Morin Ed. Québec, Canada, 850 p.

Sokal R. R., F. J. Rohlf, 1981. Biometry. The principles and practice of statistics in biological Research. 2nd ed., W. H. Freeman and co. Ed., New York, 859 p.

Solar I. I., E. M. Donaldson, G. A. Hunter, 1984. Induction of triploidy in rainbow trout (Salmo gairdneri Richardson) by heat shock, and investigation of early growth. Aquaculture, 42, 57-67.

Sutterlin A. M., L. R. Mac-Farlane, P. Harmon, 1977. Growth and salinity tolerance in hybrids within Salmo sp. and Salvelinus sp. Aquaculture, 12, 41-52.

Suzuki R., T. Nakanishi, T. Oshiko, 1985. Survival, growth and sterility of induced triploids in the Cyprinid loach Misgurnus anguillicaudatus. Bull. Jap. Soc. Sci. Fish., 51, 889-894.

Thorgaard G. H., 1983. Chromosome set manipulation and sex control in fish. In : Fish Physiology, Academic press, New York, IX, part B, 405-434.

- 1986. Ploidy manipulation and performance. Aquaculture, 57, 57-64.

Thorgaard G. H., P. S. Rabinovitch, M. W. Shen, G. A. E. Gall, J. Propp, F. M. Utter, 1982. Triploid rainbow trout identified by low cytometry. Aquaculture, 29, 305309.

Utter F. M., O. W. Johnson, G. H. Thorgaard, P. S. Rabinovitch, 1983. Measurement and potential applications of induced triploidy in Pacific salmon. Aquaculture, 35, 125-135.

Valenti R. J., 1975. Induce polyploidy in Tilapia aurea (Steindachner) by means of temperature shock treatment. J. Fish. Biol., 7, 519-528.

Wolters W. R., G. S. Libey, C. L. Chrisman. 1982. Effect of triploidy on growth and gonad development of channel catfish. Trans. Am. Fish. Soc., 111, 102-105. 